Сергій Богунов,

кандидат технічних наук

Національний університет оборони України імені Івана Черняховського ORCID ID 0000-0002-4946-1604

Ольга Черних,

Національний університет оборони України імені Івана Черняховського ORCID ID 0000-0001-9865-5598

Юрій Черних, кандидат технічних наук, доцент,

Військовий інститут Київського національного університету імені Тараса Шевченка

ORCID ID 0000-0002-0780-6627

\title{
ОСНОВИ ОРГАНІЗАЦІЇ ТА ФУНКЦІОНУВАННЯ СИСТЕМИ ВІЙСЬКОВОЇ ОСВІТИ ВЕЛИКОБРИТАНІї: АНАЛІТИЧНИЙ ОГЛЯД
}

У статті розглянуто досвід підготовки військових фахівиів для збройних сил Великобританії. Окреслено варіанти організації підготовки офіщерів на первинні посади та основні «траєкторії» ї навчання. Проведено аналіз змісту підготовки офрічерських кадрів для різних видів збройних сил. Наведено відомості щзодо існуючої мережі військових навчальних закладів для підготовки офічерів тактичної та оперативнотактичної ланок військового управління сухопутних військ, військово-повітряних сил та військово-морських сил. Визначено терміни підготовки військових фахівців на тактичному та оперативно-тактичному рівнях. Зроблено висновок щзодо якості підготовки офічерських кадрів для збройних сил Великобританії.

Ключові слова: система військової освіти; збройні сили Великобританії; досвід підготовки офіцерів.

Постановка проблеми. Застосування сучасних збройних сил, оснащених складною зброєю і військовою технікою, вимагає високого рівня військово-професійної освіти офіцерських кадрів. 3 цією метою у країнах НАТО створена сучасна, широко розгалужена система військової освіти (CBO), що забезпечує підготовку офіцерського складу за основними військово-обліковими спеціальностями для збройних сил. Знання системи військово-професійної освіти офіцерських кадрів провідних країн НАТО (США, Франції, Великобританії, Німеччини) та їі особливостей має велике значення, оскільки дає змогу точніше оцінювати можливості збройних сил щодо виконання службово-бойових завдань, а також ураховувати досвід підготовки їх офіцерського складу у військових навчальних закладах України. У ході подальшого розвитку національної СВО варто запозичувати кращі риси систем освіти інших країн, а саме: раціональність, ефективність, відкритість для цивільного контролю, функціонування відповідно до демократичних принципів освітньої діяльності тощо. 
Творче використання міжнародного досвіду підготовки офіцерських кадрів за кордоном набуває особливої актуальності в умовах упровадження стандартів НАТО у Збройних Силах (3С) України. Тому сьогодні позитивні елементи досвіду зарубіжних армій мають бути враховані при організації підготовки офіцерського складу ЗС України. У статті наведено аналіз досвіду підготовки офіцерів у збройних силах Великобританії, що виконаний під час проведення дослідження в межах науково-дослідної роботи «Удосконалення національної системи військової освіти відповідно до стандартів підготовки фахівців у навчальних закладах країн-членів НАТО» (шифр - Підготовка-Н).

Аналіз досліджень і публікацій. Дослідженню питань, пов'язаних 3 аналізом систем підготовки військових фахівців інших країн, присвячено низку наукових праць вітчизняних учених. Зокрема, підготовку офіцерських кадрів у США висвітлено у працях С. Владимирова, Н. Дрожина, В. Іващенка, К. Колчіна, В. Кружиліна, П. Лебедя, В. Ожгихіна, Р. Равлика, О. Панова, І. Попова, А. Стрелецького; у Франції - у роботах В. Владимирського, В. Захарова, О. Мітіна, О. Коп’ьєва, М. Сімакова, П. Колесова; у Німеччині - в працях К. Колчіна, В. Лазукина, Ю. Федосєєва, В. Чернова; у Великобританії - у дослідженнях В. Бровкина. Порівняльний аналіз систем підготовки військових фахівців у зарубіжних збройних силах здійснили О. Барабанщиков, М. Гацько, М. Нещадим, Б. Олексеєнко, С. Печеров, Ю. Приходько, В. Телелим, О. Челпанов, В. Ягупов. Разом із тим слід зазначити, що, незважаючи на різноманітність публікацій щодо систем військової освіти у провідних країнах, дослідження сучасного стану підготовки військових фахівців у збройних силах Великобританії наражаються на такі проблеми: застарілість наукових публікацій, неповнота й недостатня аналітичність джерельної бази, нехтування необхідністю грунтовного вивчення закордонного досвіду підготовки військових фахівців тощо.

Метою статті $\epsilon$ проведення аналізу сучасного стану СВО Великобританії для врахування досвіду підготовки офіцерських кадрів під час подальшої реформи національної системи військової освіти.

Методи досліджень. Для розв'язання поставлених завдань використано систему загальнонаукових i спеціальних методів теоретичного та емпіричного дослідження, а саме: аналіз наукової літератури 3 проблеми дослідження, систематизація та узагальнення наукової інформації, моніторинг існуючої системи підготовки військових фахівців у збройних силах Великобританії, загальнонаукові методи логічного й порівняльного аналізу, системного підходу, експертна оцінка, аналіз та інтерпретація отриманих теоретичних й емпіричних даних.

Виклад основного матеріалу. Адаптація системи підготовки офіцерських кадрів збройних сил Великобританії до нових вимог, що почалася в середині 90-х років минулого століття, насамперед, пов'язана зі змінами, що відбувалися в системі їх комплектування. Офіцерський склад ЗС 
Великобританії в теперішній час поділяється на кадрових офіцерів та офіцерів короткотермінової служби [1].

Основним джерелом комплектування ЗС кадровим офіцерським складом $\epsilon$ військові навчальні заклади (коледжі). Крім того, частину кадрових офіцерів набирають із числа осіб, які закінчили цивільні ВН3 і пройшли курси за обраним фахом у відповідних військових училищах або школах родів військ та служб [2, 11-16]. Офіцери короткотермінової служби укладають контракти на термін до трьох років, маючи можливість після отримання дозволу відбірної комісії міністерства оборони подовжити його до восьми років. Кандидати в офіцери короткотермінової служби повинні пройти відбірну комісію міністерства оборони та курс підготовки за обраним фахом. Після двох років служби у ЗС вони мають право звернутися з проханням про переведення до кадрового складу [3].

Загальне керівництво комплектуванням і підготовкою особового складу, зокрема офіцерського, здійснює управління особового складу й резервів, підпорядковане заступникові начальника штабу оборони ЗС Великобританії. Безпосереднє керівництво покладено на штаби видів 3С: у сухопутних військах (CB) - на управління розроблення доктрини $\mathrm{CB}$ i навчання особового складу, у військово-повітряних силах (ВПС) - на управління особового складу ВПС, у військово-морських силах (ВМС) - на управління підготовкою офіцерського складу й комплектування ВМС [1].

Основним військовим навчальним закладом сухопутних військ, що здійснює підготовку молодшого офіцерського складу для всіх родів військ і служб є військове училище в м. Сандхерст [4; 5]. Щороку воно випускає близько 1200 офіцерів кадрової та короткотермінової служби. Училище на 70 \% забезпечує потреби ЗС у молодих офіцерах.

Підготовка офіцерського корпусу характеризується цілісністю i безперервністю. Початкова військово-спеціальна i військово-професійна підготовка офіцерів сухопутних військ відбувається у військовому училищі. У подальшому вони проходять допідготовку й перепідготовку на курсах підвищення кваліфікації (вдосконалення) в центрах відповідних родів військ. Водночас у сухопутних військах Великобританії відсутні вищі військовонавчальні заклади, а Сандхерстське військове училище є середнім військовонавчальним закладом [6].

Головним контингентом, на базі якого комплектується склад курсантів (слухачів) військового училища, є: юнаки та дівчата із середньою освітою віком від 17,5 до 20 років, які мають хороші показники в навчанні; військовослужбовці віком до 25 років; випускники цивільних ВНЗ віком до 25 років [3].

Студенти цивільних університетів мають право укласти контракт на проходження військової служби у збройних силах Великобританії терміном не менше п'яти років. Після двомісячної підготовки в Сандхерстському військовому училищі в період навчання в університеті (за два роки до його закінчення) вони отримують тимчасове військове звання «лейтенант» i грошове утримання від міністерства оборони на період закінчення навчання в 
університеті. Випускники університету повертаються до військового училища в якості офіцерів-слухачів і проходять курс військової підготовки. Потім направляються до військ для проходження військової служби відповідно до укладеного контракту.

Учні середніх шкіл укладають контракти за два роки до закінчення навчального закладу. У цьому випадку військове відомство оплачує навчання i надає їм підтримку в інших областях [1]. За час навчання школярі займаються в системі позавійськової підготовки молоді. Їх добровільна участь у військових зборах передбачає додаткову фінансову винагороду. Після закінчення Сандхерстського училища офіцери цієї категорії зобов'язані прослужити у збройних силах не менше трьох років. До такої форми навчання можуть залучатися також студенти середніх технічних i спеціалізованих коледжів, політехнічних інститутів, молоді робітники.

Навчання у військовому училищі розділено на два етапи [4]. Перший базовий, що складається з курсу терміном до 44 тижнів, а потім залежно від обраної спеціальності курсант проходить додаткові курси різної тривалості.

Загальна програма навчання розрахована на три періоди (по 14 тижнів кожний). Її тривалість для осіб із вищою освітою складає 28 тижнів. Навчальна програма містить такі навчальні дисципліни: тактика, стройова, вогнева та фізична підготовка, воєнна історія, топографія, зв'язок, інформатика, організація військ, військове законодавство тощо. Значна увага приділяється прищепленню курсантам (слухачам) командирських (лідерських) навичок, заняттям спортом та участі в тактичних навчаннях. На заключному етапі навчання майбутніх офіцерів відправляють на стажування у війська, причому туди, де їм найімовірніше доведеться проходити подальшу військову службу [5].

Однак навчання у військовому училищі не обмежується вивченням тільки військових дисциплін. Офіцер, на думку керівництва ЗС Великобританії, повинен, насамперед, завоювати авторитет у підлеглих, використовуючи інтелектуальні здібності. Саме тому в училищі вивчаються загальноосвітні навчальні дисципліни: психологія, етика, питання поведінки в суспільстві тощо.

Випускникам училища присвоюється первинне офіцерське звання другий лейтенант. Вони розподіляються на курси спеціалізації в навчальні центри (школи) і в частині родів військ та служб (піхотні, артилерійські, зв'язку, інженерні, розвідки тощо), де вдосконалюють здобуті знання та навички за обраним фахом. Тривалість навчання становить від кількох тижнів до кількох місяців [6].

Крім цього, деякі офіцери технічних спеціальностей, які не мають вищої освіти, можуть бути направлені для подальшого навчання до цивільних університетів або до Шрівенгемського військово-наукового коледжу. Офіцери мають право здобувати вищу освіту в обраному ними цивільному вищому навчальному закладі за будь-якою спеціальністю. 
Порядок проходження військової служби офіцерським складом передбачає набуття досвіду як на штабних посадах, так і безпосередньо у військах. При цьому важливим елементом професійної підготовки офіцерського складу є система ротації при проходженні військової служби, що полягає в обов'язковому періодичному (через 2-3 роки) чергуванні перебування на командних і штабних посадах.

Навчальні заклади ВПС Великобританії комплектуються в основному кандидатами, які пройшли первинну льотну підготовку в авіаційному кадетському корпусі [7]. Останній являє собою широко розгалужену по всій країні організацію ВПС і призначений для навчання молоді теоретичним основам авіації, а також практичному виконанню польотів. У складі цього корпусу служать офіцери та унтер-офіцери ВПС, а навчаються - кадети віком від 13 до 20 років. У ньому налічується 13 авіаційних ланок, оснащених поршневими навчально-тренувальними літаками «Чипмунк» $\mathrm{i}$ «Буллдог», а також 27 планерних шкіл.

Комплектує навчальні заклади ВПС центр із відбору молоді в м. Біггін Хілл. Після прибуття в центр кандидати протягом чотирьох днів проходять медичну комісію та тестування 3 метою виявлення їх здібностей і рівня загального розвитку. Тести містять перевірку знань елементарної математики та здатностей до розподілу уваги й координації рухів. Кандидати, які успішно впоралися 3 ними, розбиваються на навчальні групи по шість осіб, що формуються для визначення їх управлінських здібностей. Вони опрацьовують різні тести 3 управління групою або виконують певні самостійні дії під спостереженням членів приймальної комісії.

Відібраних кандидатів центр розподіляє в такий спосіб: тих, кому необхідно отримати вищу освіту, направляють на навчання в університети, а тих, хто вже має вищу або середню освіту - до навчального центру загальновійськової та спеціальної підготовки авіаційного коледжу в м. Крануелл. Цей коледж $є$ основним навчальним закладом, що забезпечує ВПС льотним та інженерним складом [8].

Ті кандидати, яких відібрали для здобуття вищої освіти, зараховуються до відповідних вищих цивільних навчальних закладів, для чого міністерство оборони Великобританії резервує місця в них і виділяє необхідні кошти. Студенти, придатні до льотної роботи, без відриву від навчання проходять льотну підготовку на літаках «Буллдог» у так званих університетських ескадрильях. Усього в країні є 16 таких ескадрилій, що забезпечують навчання студентів 46 університетів за різними авіаційними спеціальностями, навіть льотними [7]. Крім того, у них проходять підготовку протягом двох років члени добровільного резерву. До моменту закінчення навчального закладу студенти завершують і курс льотної підготовки. Середній загальний наліт становить 95 годин, із яких 48 витрачається на відпрацьовування техніки пілотування, 18,5 - вивізні та контрольні польоти, 10 - польоти по приладах, 9 - літаководіння, а 6 годин - на групову злітаність і 3,5 години - польоти на малих висотах. 
У зв'язку з нестачею кандидатів для проходження військової служби, які мають вищу освіту, командування ВПС змушене приймати певний відсоток осіб із дещо нижчим освітнім рівнем, в основному, із числа осіб, які знаходяться в добровільному резерві при університетських ескадрильях i мають наліт не менше 30 годин на поршневому навчально-тренувальному літаку «Буллдог». Ця категорія кандидатів перед зарахуванням у навчальні заклади ВПС направляється в ескадрилью по відбору льотного складу (аеродром Свиндерби). Там вони проходять додаткову навчальну програму льотної підготовки (15 годин, навчальний літак «Чипмунк»). У пї ході відбувається відрахування безперспективних кандидатів, що досягає $25 \%$ осіб, які приступили до виконання польотів.

Подальша підготовка офіцерів ВПС здійснюється в навчальному центрі загальновійськової та спеціальної підготовки авіаційного коледжу в м. Крануелл. Програма підготовки майбутніх офіцерів дуже складна, оскільки служба у ВПС ставить до них високі вимоги. Коледж дає курсантам теоретичні знання та практичні навички з багатьох навчальних дисциплін, високу фізичну та морально-психологічну підготовку, що є базою для їх дальшого розвитку й підвищення кваліфікації.

Після проходження загальновійськової та теоретичної авіаційної підготовки курсанти направляються у льотні школи. Їхня навчальна програма складається з курсів основної і підвищеної підготовки, бойового застосування та переучування на конкретні типи бойових літаків і вертольотів.

Курс основної льотної підготовки для курсантів, які мають вищу освіту, розрахований на 31 тиждень. За цей час кожен із них у середньому має налітати 77 годин на реактивному навчальному літаку «Джет Провост-Т.5». Для курсантів, які мають середню освіту i не завершили повноцінну первинну льотну підготовку, цей курс триває 37 тижнів. Він містить заняття на наземному тренажері (24 години) і 97 годин нальоту на літаку «Джет Провост-Т.3» або його поліпшеному варіанті - «Джет Провост-Т.5».

Льотна підготовка слухачів здійснюється в навчальних ескадрильях авіаційного коледжу та льотних школах № 1 (аеродром Чеч Фентон) [9] і № 7 (аеродром Лінтон-на-Озе). Після проходження цього курсу передбачений відсів не більше $20 \%$ від загальної чисельності тих, хто навчається. Курсанти, які закінчили курс, з урахуванням їх індивідуальних здібностей і потреб ВПС у льотних кадрах для різних родів авіації розділяються на три групи:

№ 1 - льотчики реактивних винищувачів («Фантом», «Торнадо», «Ягуар», «Харріер» тощо);

№ 2 - льотчики багатомоторних важких літаків («Німрод», «Геркулес»);

№ 3 - льотчики вертольотів.

Курс підвищеної льотної підготовки для кожної групи ділиться на два етапи.

Перший етап для групи № 1 (15 тижнів) містить 5 годин занять на тренажері та 58 годин нальоту на літаку «Джет Провост-Т.5». Другий етап триває 24 тижні. Навчання здійснюється у льотній школі № 4 (літак «ХокT.1», аеродром Валлі). Програма містить наземну підготовку, тренування на тренажерах і льотну підготовку. 
Наземна підготовка (230 годин) проводиться протягом восьми тижнів перед початком практичних польотів і в ході польотів перед кожним новим видом підготовки. У процесі їі курсанти вивчають інструкцію 3 техніки пілотування та експлуатації літака, порядок виконання польотів, аеродинаміку, літаководіння, радіозв'язок, авіаційну медицину, метеорологію, засоби порятунку, озброєння й тактику тощо. На відпрацювання дій льотчика 3 виконання різних етапів польоту виділяється до 40 годин тренувань у кабіні літака.

У ході наземної та льотної підготовки широко використовуються тренажери. Програма тренування льотчиків на них передбачає вироблення навичок, необхідних для виконання польотів, і містить 16 вправ. Загальний «наліт» на тренажерах становить 20 годин, але для окремих курсантів він може бути збільшений до 25 годин і більше.

Програма льотної підготовки розрахована на шість місяців і передбачає середній наліт на курсанта 85 годин, із них більше 50 \% виділяється на самостійні польоти. У ході навчання льотний склад відпрацьовує польоти по колу, у зону на простий і складний пілотаж (40 годин), по приладах у закритій кабіні (10 годин), літаководіння (8 годин), польоти вночі (10 годин), групову злітаність (10 годин) та інші завдання (7 годин).

Після успішного закінчення другого етапу курсанти групи № 1 отримують льотну кваліфікацію «крило» і направляються в центри бойового застосування, а частина 3 них, приблизно до $5 \%$, - у центральну льотну школу підготовки інструкторів (аеродром Лімінг). Відсів курсантів на цьому етапі не має перевищувати $25 \%$. Ті особи, які не виявили якостей, необхідних для льотчика тактичної винищувальної авіації, можуть бути переведені у групу № 2 або № 3 чи відраховані.

Перший етап курсу підвищеної льотної підготовки для групи № 2 (8 тижнів) містить 9 годин занять на тренажері та 27 годин нальоту на літаку «Джет Провост-Т.З». Другий етап триває 20 тижнів, протягом яких кожному курсанту виділяється 45 годин для занять на тренажері та 45 годин нальоту на літаку «Джетстрим». Льотчики навчаються у льотній школі № 3 (аеродром Лімінг), а штурмани - у школі № 6 (аеродром Фіннінглі). Крім того, в останній разом із технічною школою в м. Тонкліф здійснюється підготовка бортінженерів та операторів бортового обладнання. Відсів курсантів у ході проходження курсу не має перевищувати $12 \%$. Відраховані особи можуть продовжувати навчання за програмою групи № 3 або у школах підготовки наземного обслуговуючого персоналу.

Перший етап курсу підвищеної льотної підготовки для групи № 3 розрахований на 17 тижнів, коли кожен курсант повинен налітати 76 годин на вертольотах «Газель». Навчання проводиться у льотній школі № 2 (аеродром Шоберн). Другий етап триває 11 тижнів (наліт 50 годин на вертольотах «Уессекс»). Слухачі, відібрані для польотів на вертольотах пошуково-рятувальної служби, проходять додаткову підготовку на аеродромі Валлі. У ході iї вони відпрацьовують дії щодо пошуку та порятунку екіпажів, що потерпіли аварії в гірській місцевості та над морем (наліт 10 годин). 
Після завершення курсу підвищеної льотної підготовки випускники груп № 1, № 2 і № 3 отримують льотну кваліфікацію «крило» і направляються в навчально-бойові підрозділи для переучування на бойову техніку, на якій їм доведеться літати у стройових частинах.

Курс бойового застосування призначений тільки для слухачів групи № 1 , які будуть служити в тактичній винищувальній авіації та протиповітряній обороні. Він розрахований на 18 тижнів (17 годин занять на тренажері та 57 годин нальоту на навчально-бойовому літаку «Хок») і проводиться в навчальних центрах бойового застосування № 1 (аеродром Вроуди ) і № 2 (аеродром Чайвинор).

Підготовка інструкторів для навчальних частин i підрозділів ВПС здійснюється в центральній льотній школі. У ній $є$ сім авіаційних ескадрилій: чотири розташовані на аеродромі Лімінг (дві оснащені літаками «Джет Провост», одна - «Буллдог», а ескадрилья стандартизації та оцінки навчання використовує літаки трьох вищевказаних типів), одна ескадрилья - на аеродромі Валлі (літаки «Хок»), одна - аеродромі Шоубері (вертольоти «Газель») та одна - на аеродромі Сіерстон (планери). Центральній льотній школі підпорядкована також ескадрилья вищого пілотажу «Ред Ерроуз» (літаки «Хок», аеродром Кембл).

Повний курс льотчика-інструктора триває 26 тижнів, протягом яких рівень його майстерності доводять до категорії В 2 (загальний наліт при цьому становить 100 годин на літаках і 65 годин на вертольотах). Програма навчання передбачає підготовку як у методичному відношенні, так і льотну, включаючи польоти у складних метеорологічних умовах і вночі.

Після завершення підготовки інструктори мають право працювати у льотних школах, авіаційному коледжі, а також спеціальній ескадрильї відновлення втрачених навичок (входить до складу льотної школи № 4). У ході практичної діяльності та в разі досягнення нальоту 250 годин (як інструктор) льотчик може підвищити свою кваліфікацію до категорії В 1.

Курси переучування на конкретні типи бойових літаків розрізняються за тривалістю навчання та кількістю годин нальоту, що залежать від ступеня складності авіаційної техніки. У цілому підготовка льотчика (включаючи навчання у вищому цивільному навчальному закладі) займає 5-5,5 років. За цей період наліт льотчика 3 групи № 1 становить 335-375 годин, № 2 - 210348 годин, № 3 - 243-305 годин (залежно від типу літального апарата).

Підготовка льотного складу є однією з найбільш тривалих і коштовних форм навчання. Особливо це стосується екіпажів сучасних бойових літаків, головним чином через високу вартість матеріальної частини та великих витрат, пов'язаних 3 іï експлуатацією. Так, на навчання льотчика до отримання ним кваліфікації «крило» витрачається більше 0,5 млн. фунтів стерлінгів. Витрати ж на його навчання бойовому застосуванню літака та зброї, включаючи переучування (до приходу у стройову частину), становлять до 2,0 млн. фунтів стерлінгів. Однак, у зв'язку з некомплектом льотного складу в бойовій авіації командування ВПС Великобританії має намір вжити 
таких заходів для ліквідації неукомплектованості частин і підвищення ефективності систем відбору та підготовки льотчиків: модернізувати літаковий парк навчальних підрозділів ВПС, удосконалити програми підготовки офіцерів ВПС, збільшити набір кандидатів на конкурсні екзамени до навчальних закладів ВПС, поліпшити систему конкурсних випробувань кандидатів з урахуванням досвіду інших країн, підсилити пропаганду 3 метою залучити бажаючих служити у ВПС, збільшити кількість і поліпшити якість тренажерів для підготовки льотного складу тощо.

Початкова підготовка кадрового офічеерського складу ВМС здійснюється в Королівському військово-морському коледжі [10] в м. Дартмут. Тут навчаються офіцери стройової, інженерно-технічної та адміністративногосподарської служб. До коледжу приймають військовослужбовців, а також осіб із числа цивільної молоді. Одночасно у ньому навчається близько 450 курсантів.

Протягом першого року навчання всі вони проходять загальну морську підготовку. За результатами року їм присвоюється військове звання «головний старшина». Під час другого навчального року вони проходять військову службу на бойових кораблях. Дублюючи посади офіцерів, курсанти на практиці відпрацьовують питання управління кораблем, несення служби, кораблеводіння тощо. Стажування закінчується екзаменом, після складання якого їм присвоюють тимчасове військове звання «молодший лейтенант». Подальша підготовка проводиться таким чином: молодші лейтенанти стройової та адміністративно-господарської служб повертаються до Королівського військово-морського коледжу, де впродовж третього року навчання опановують загальноосвітні дисципліни. На четвертому році навчання вони проходять підготовку в різних навчальних центрах ВМС. Офіцери вивчають навігацію, зв'язок, озброєння та інші предмети, офіцери адміністративно-господарської служби - організацію постачання, складування запасів, діловодство, законодавство, організацію адміністративної служби.

Після чотирьох років навчання офіцерам стройової та адміністративногосподарської служб присвоюють постійне військове звання «молодший лейтенант» і направляють на флот для проходження військової служби.

Більшість курсантів, яких відібрано для служби за інженерно-технічним фахом, після стажування на флоті направляють до Військово-морського інженерного коледжу в м. Плімут [11]. Там вони вивчають загальноосвітні та загальнотехнічні дисципліни, а також спеціальні навчальні дисципліни 3 електротехніки чи механіки. Курс навчання завершується випускними екзаменами, після чого їм присвоюють військове звання «лейтенант» i видають диплом бакалавра.

Штурмани-оператори після підготовки в Королівському військовоморському коледжі продовжують навчання у військово-морському коледжі, де їм читають лекції 3 радіолокації, гідроакустики, гідрології та інших спеціальних дисциплін. Після проходження атестаційної комісії їх 
направляють до військово-морської школи штурманів-операторів для підготовки за фахом.

Перед підвищенням на посаді офіцери, як правило, проходять короткотермінові курси підвищення кваліфікації. Наприклад, командири механізованих взводів і рот підвищують свою кваліфікацію в піхотній школі, командири артилерійських взводів, батарей - в артилерійській школі, командири підрозділів зв'язку - у школі зв'язку. У військово-повітряних силах курси перепідготовки на конкретні типи бойових літаків i вертольотів організовують у навчально-бойових ескадрильях. Термін навчання у цих школах залежить від рівня складності озброєння та військової техніки.

Головним військово-навчальним закладом із підготовки старших офіцерів оперативно-тактичної ланки управління $\epsilon$ Академія оборони Великобританії [12]. Академія оборони взяла на себе функції не тільки підготовки офіцерів середньої та вищої ланки, а й проведення досліджень 3 оборонної тематики. Навчання слухачів у ній головним чином спрямоване вивчення питань менеджменту в галузі оборони.

Організаційно до складу Академії оборони Великобританії входять: Об'єднаний командно-штабний коледж, Королівський військовий коледж науки, Група проведення поглиблених досліджень і оцінок, Королівський коледж оборонних досліджень, Центр Капеланів 3С Великобританії. Ядром академії є Об’єднаний командно-штабний коледж [13], у якому навчаються офіцери середньої і вищої ланки усіх видів збройних сил. На коледж покладено відповідальність також за підготовку на чотиримісячних курсах молодших офіцерів, на які направляють офіцерів віком 25-30 років (курс початкової командно-штабної підготовки - тактичний рівень). Щороку організовують три курси по 180 осіб. Їх завдання - підготовка молодших офіцерів для служби на посаді майора у військах та штабах. Програма містить п'ять основних груп питань: міжнародні відносини, оборонна політика Великої Британії і роль збройних сил, тактична підготовка, штабна служба і тилове забезпечення, керівництво підлеглими. Тривалість курсів для офіцерів ВМС - 8 тижнів, ВПС - до 4-х тижнів, СВ - 7-8 місяців. Усього через курси початкової підготовки щорічно проходить до 1950 осіб. Крім того, усі офіцери сухопутних військ і військово-повітряних сил мають пройти обов'язковий тритижневий командний курс для молодих офіцерів i річний курс заочного навчання.

На основний курс штабного коледжу (поглиблений курс - оперативний рівень) приймають офіцерів у військових званнях «майор» $\mathrm{i}$ «підполковник» віком 30-40 років. Термін навчання - 42 тижні (3 вересня по липень). У коледжі щороку навчається близько 400 осіб. Головне завдання основного курсу - поглибити знання слухачів із таких питань: внутрішня та зовнішня політика уряду і роль збройних сил, принципи застосування збройних сил у загальній війні й локальних війнах (вивчення оборонних та наступальних операцій), миротворчі операції з підтримання миру, боротьби 3 тероризмом, управління військами в мирний та воєнний час, використання засобів 
управління, організація розвідки, аналіз розвідувальних даних в інтересах прийняття оптимального рішення, техніко-тилове забезпечення та адміністративне управління.

Значна увага під час навчання приділяється організації взаємодії між видами збройних сил. Перед початком курсу проводиться 4-х тижневий курс спеціалізації. На нього приймають офіцерів, які брали участь в операціях і мають досвід бойових дій. На курсі навчаються також до 90 іноземців майже 3 50 країн світу (з країн НАТО, британської співдружності, країн-учасниць Програми заради миру та інших). По завершенні курсу слухачі можуть захистити наукову роботу з метою отримання освітнього ступеня «магістр»[14].

На території академії розташований Королівський військовий коледж наук. Між ним та університетом м. Кранфілд укладений так званий «академічний контракт», згідно з яким університет залучається до навчання військових слухачів із загальних навчальних дисциплін, а також бере участь у дослідженнях оборонного характеру.

Королівський військовий коледж наук [15] підпорядковується командуванню сухопутних військ, крім того, готує наукові кадри для військовоповітряних сил і військово-морських сил. У цьому закладі здійснюється вища військово-технічна підготовка офіцерського складу. У коледжі функціонує навчальний курс штабної служби. Перспективні офіцери віком 30-33 роки, які мають вищу освіту в галузі технічних чи природознавчих наук, навчаються протягом 10 місяців на першому відділенні курсу штабної підготовки. Офіцерів iз нижчим рівнем підготовки у цих науках зараховують на друге відділення курсу, де навчання триває 11 місяців. Офіцери інших категорій протягом двох місяців навчаються на третьому відділенні. Програма передбачає вивчення основних питань організації виробництва й закупівлі військової техніки. На третьому відділенні слухачів знайомлять тільки 3 основами військової технології. На першому і другому відділеннях одночасно навчається приблизно по 50 осіб, на третьому - до 100 чоловік.

Висновки та перспективи подальших досліджень. Динамічні процеси, які відбуваються під час реформування системи військової освіти у Великобританії, свідчать про те, що стратегія ऑiі розвитку передбачає багатоступеневість і неперервність здобуття та удосконалення освіти протягом усієї військової служби офіцера. Аналіз СВО у Великобританії демонструє, що вона дає можливість офіцерському складу протягом усієї військової служби періодично вдосконалювати свою професійну компетентність. При цьому передбачається використання широкої мережі спеціалізованих навчальних центрів родів військ, центрів практичної підготовки, курсів для здобуття практичних умінь і навичок за майбутнім посадовим призначенням. Практична підготовка офіцерських кадрів має тенденцію поділу на первинну загальновійськову підготовку і спеціальну військову підготовку. Майбутні офіцери, навчаючись у ВВНЗ, проводять значний час на стажуваннях у військах, а у процесі підвищення кваліфікації чи перепідготовки їх залучають до участі в різноманітних військових навчаннях. Після закінчення ВВНЗ видів 
військ або цивільного ВНЗ та перед призначенням на посаду випускники продовжують свою практичну підготовку у військових училищах (школах) або навчальних центрах родів військ. Зміст військової освіти орієнтований на: оптимальне співвідношення гуманітарної, природничо-наукової та спеціальної (професійної) складових, вузьку спеціально-професійну спрямованість підготовки військових фахівців усіх рівнів і ланок управління, підготовку військових фахівців із вищою освітою на засадах інтеграції військових навчальних закладів із відповідними цивільними ВН3 з урахуванням специфіки майбутньої військово-професійної діяльності офіцера. Отже, досвід організації та вдосконалення CВО у Великобританії може бути корисним для вирішення проблем реформування вітчизняної системи військової освіти.

\section{ЛІТЕРАТУРА}

1. British Army. [Електронний ресурс]. - Режим доступу: http://en.wikipedia.org/wiki/British_Army.

2. Бровкин В. Подготовка военнослужащих Великобритании// Зарубежное военное обозрение. - 2005. - № 1. - С. 11-16.

3. Selection and Training in the British Army [Електронний ресурс]. - Режим доступу: http://en.wikipedia.org/wiki/Army_Training_Regiment.

4. Royal Military College Sandhurst [Електронний pecypc]. - Режим доступу: https://en.wikipedia.org/wiki/Royal_Military_College,_Sandhurst.

5. Defense Academy of the United Kingdom [Електронний ресурс]. - Режим доступу: http://www.da.mod.uk/.

6. Infantry Training Centre [Електронний pecypc]. - Режим доступу: http://en.wikipedia.org/wiki/Infantry_Training_Centre.

7. Air Experience Flight [Електронний pecypc]. - Режим доступу: http://military.wikia.com/wiki/Air_Experience_Flight.

8. Royal Air Force College Cranwell [Електронний pecypc]. - Режим доступу: https://en.wikipedia.org/wiki/Royal_Air_Force_College_Cranwell.

9. Flying Training School No. 1 (1 FTS) [Електронний pecypc]. - Режим доступу: https://en.wikipedia.org/wiki/No._1_Flying_Training_School_RAF.

10. Britannia Royal Naval College [Електронний ресурс]. - Режим доступу: http://en.wikipedia.org/wiki/Britannia_Royal_Naval_College.

11. Royal Naval Engineering College [Електронний ресурс]. - Режим доступу: http://en.academic.ru/dic.nsf/enwiki/11444807.

12. Defence Academy of the United Kingdom [Електронний ресурс]. - Режим доступу: http://www.da.mod.uk/.

13. Joint Services Command and Staff College [Електронний ресурс]. - Режим доступу: http://en.wikipedia.org/wiki/Joint_Services_Command_and_-Staff_College.

14. Royal College of Defence Studies [Електронний ресурс]. - Режим доступу: https://en.wikipedia.org/wiki/Royal_College_of_Defence_Studies.

15. Advanced Research and Assessment Group [Електронний ресурс]. - Режим доступу: https://en.wikipedia.org/wiki/Advanced_Research_and_-Assessment_Group.

\section{REFERENCES}

1. British Army. [Elektronnij resurs] - Rezhim dostupu: http://en.wikipedia.org/wiki/British_Army.

2. Brovkin V. (2005). Training of the military personnel of Great Britain//Foreign military review. - No. 1. - Page 11-16. (In Russian).

3. Selection and Training in the British Army [Elektronnij resurs] - Rezhim dostupu: http://en.wikipedia.org/wiki/Army_Training_Regiment.

4. Royal Military College Sandhurst [Elektronnij resurs] - Rezhim dostupu: 
https://en.wikipedia.org/wiki/Royal_Military_College_Sandhurst.

5. Defense Academy of the United Kingdom [Elektronnij resurs] - Rezhim dostupu: http://www.da.mod.uk/.

6. Infantry Training Centre [Elektronnij resurs] - Rezhim dostupu: http://en.wikipedia.org/wiki/Infantry_Training_Centre.

7. Air Experience Flight [Elektronnij resurs] - Rezhim dostupu: http://military.wikia.com/wiki/Air_Experience_Flight.

8. Royal Air Force College Cranwell [Elektronnij resurs] - Rezhim dostupu: https://en.wikipedia.org/wiki/Royal_Air_Force_College_Cranwell.

9. Flying Training School No. 1 (1 FTS) [Elektronnij resurs] - Rezhim dostupu: https://en.wikipedia.org/wiki/No._1_Flying_Training_School_RAF.

10. Britannia Royal Naval College [Elektronnij resurs] - Rezhim dostupu: http://en.wikipedia.org/wiki/Britannia_Royal_Naval_College.

11. Royal Naval Engineering College [Elektronnij resurs] - Rezhim dostupu: http://en.academic.ru/dic.nsf/enwiki/11444807.

12. Defence Academy of the United Kingdom [Elektronnij resurs] - Rezhim dostupu: http://www.da.mod.uk/.

13. Joint Services Command and Staff College [Elektronnij resurs] - Rezhim dostupu: http://en.wikipedia.org/wiki/Joint_Services_Command_and_-Staff_College.

14. Royal College of Defence Studies [Elektronnij resurs] - Rezhim dostupu: https://en.wikipedia.org/wiki/Royal_College_of_Defence_Studies.

15. Advanced Research and Assessment Group [Elektronnij resurs] - Rezhim dostupu: https://en.wikipedia.org/wiki/Advanced_Research_and_-Assessment_Group.

\section{PЕЗЮМЕ}

$$
\begin{array}{r}
\text { Сергій Богунов, } \\
\text { кандидат технических наук, } \\
\text { Национальный университет обороны Украины } \\
\text { имени Ивана Черняховского } \\
\text { Ольга Черных, } \\
\text { Национальный университет обороны Украины } \\
\text { имени Ивана Черняховского } \\
\text { Юрий Черных, } \\
\text { кандидат технических наук, доцент } \\
\text { Военный институт Киевского национального } \\
\text { университета имени Тараса Шевченко }
\end{array}
$$

\section{Основы организации и функционирования системы военного образования Великобритании: аналитический обзор}

В статье рассмотрен опыт подготовки военных специилистов для вооруженных сил Великобритании. Указаннь варианть организаџии подготовки офицеров на первичные должности и основные «траектории» их обучения. Приведены требования к лицам, поступаюшим в военные учебные заведения различных ступеней подготовки. Обозначены сведения о существующей сети военных учебных заведений для подготовки офицеров тактического и оперативно-тактического уровней военного управления сухопутных войск, военно-воздушных сил и военно-морских сил. Определены сроки подготовки военных спеииалистов на тактическом и оперативно-тактическом уровнях. Сделан вывод о качестве подготовки офицерских кадров для вооруженных сил Великобритании.

Ключевые слова: система военного образования; вооруженные силь Великобритании; опыт подготовки офицеров. 
 \\ Serhii Bohunov, \\ $\mathrm{PhD}$ (technical sciences), \\ Olga Chernykh, \\ National Defense University of Ukraine \\ named after Ivan Cherniakhovski \\ Yuri Chernykh, \\ $\mathrm{PhD}$ (technical sciences), Associate Professor, \\ Military institute of Taras Shevchenko National University of Kyev

\section{Basics of organization and functioning of the Great Britain military education system - analytical review}

The creative use of international experience in officer personnel training abroad becomes of particular relevance in the context of the implementation of NATO standards in the Armed Forces of Ukraine. Therefore, in modern conditions, positive elements of the experience of foreign armed forces should be taken into account when organizing the training of the officers of the Ukrainian Armed Forces.

The purpose of the article is to conduct an analysis of the current state of the UK military education system in order to take into account the experience of officer personnel training during the further reform of the national military education system.

To solve the research tasks we used the system of general scientific and special methods of theoretical and empirical research, namely, theoretical and methodological analysis of the problem, the analysis of scientific literature on the problem of research, classification and synthesis of scientific information regarding the nature and content of certain tasks, monitoring of the existing system training of military specialists in the British Armed Forces, scientific generalization, general scientific methods of logical and comparative analysis, system approach, expert assessment, analysis and interpretation of the obtained theoretical and empirical data.

The dynamic processes that are taking place during the reform of the military education system in the UK indicate that its development strategy implies multistage and continuity in gaining and improving education throughout the military service of an officer. The analysis of military education in the UK shows that it enables officers to improve periodically their professional competence throughout the military service. In this case, it is envisaged to use a wide network of specialized training centers of the branches of the armed forces, centers of practical training, courses for obtaining practical skills and skills for the future official appointment. Practical training of officer personnel has a tendency to be divided into basic military training and special military training. Future officers, while studying at a higher military educational institution, spend a great deal of time in internships, and in the process of refresher training or retraining, officers are involved in various military exercises. After graduation and before appointment, graduates continue their practical training in military academies (schools) or educational centers of the branches of the armed forces.

The content of military education is focused on: the optimal ratio of humanitarian, natural sciences and special (professional) components; on narrow special (professional) orientation of military specialists' training of all levels of command; on the training of military specialists with higher education on the basis of the integration of military educational institutions with the corresponding civil higher educational institutions, taking into account the specifics of the future military-professional activity of the officer. Thus, the experience of organizing and improving the training of officers in the UK can be useful in solving the problems of reforming the domestic military educational system.

Key words: military education system; armed forces of Great Britain; officers' training experience. 